\title{
日立造船型連續式セミケミカルパルプ 製造裝置についで
}

(1) 概說

日立造船は歐米諸國のセミケミカル・パルプ工業化 の趨勢及び日本に扣ける森林資源, 特に從來パルプ原 料であつた針葉樹の枯渴しつつある現狀に注目し，七 ミケミカル・パルプ製造法について種々試驗・研究を 重ね，業界にさきがけて日立造船獨特の二段連續蒸煮 式セミケミカル・パルプ製造装置を完成いたしました。 本装置はパルプの品質・步留り及び装置の作働狀況等 について極めて優秀な成緩を抢さめ，業界各位より好 評を得て沏ります。

日立造船（舊社名「大阪聝工所」一O. I. W.）の化 工機部門は創業以來70有狳年の歷史を有するもので, パルプ及び製紙用各種機器慜作には專門メーカーとし て豐富な經驗を有し，常に新しい試驗・研究と最新の 工作機戌設備により, 新時代の要求に應じうる高性能 機器の設計・製作に不斷の努力をいたして扣ります。

特に木材チップを蒸者する木釜は眧和11年頃よりそ の製作基數は既に S. P., K. P. 用で約 140 基に達し 又昭和 24 年以來業界にさきがけてパルプ製造工程中の 吒解部門に對する獨自の研究改善を行い最新のディス クレファイナー, コーン型レファイナー, 㹂型レファ イナー等を製作しております。

\section{(2) 日立造沿型連續式セミケミカル・ パルプ製造裝置の特徵}

日立造船式セミケミカル・パルプ製透裝置は 日野三郎氏の特許により日立造船にて工業化の ため種々研究し，設計・製作したもので，本裴 置の特徵は次のものであります。

（a）本裝置は低壓蒸煮室のスチーミングベッ セルと高壓蒸薏室のリアクションチャンバーと で二段蒸竟を逨續的に行5ようにしたものであ ります。邲ら低壓蒸者室では木材チップは豫脩

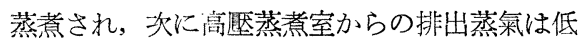
壓蒸薏室の蒸薏蒸氣として有効に利用されます ので熱損失は非常に少いものとなります。

(b) 裝置全體は連續工程方式を探用して掠 り，溫度・壓力・反應時間等はその泟求する紙 質によりその條件は容易に變学ることができ， 運轉中はそれぞれ自動制禦することができす * 原稳受付 30.4 .20
日立造船株式會䇅

す。また浦續式でありますので，高溫の蒸氣壓力下で レファイナーによりパルプ繊維を機械的に高能率に離 解することができます。

（c）パルプ生産費低減のために，裝置全體に動力並 びに蒸氣の有効利用のための配虑が十分なされて和り ます。また建家及び機器の据付にはあまり大きな面積 を必要としないので他のパルプ・プラントに比較して 設㣁費は低廉であります。(本裝置は特許並びに實用新 案沙製作されて和ります。?

\section{（3） 日立造船型連續式セミケミカル・ パルプ製造裝置の構造}

この装置の構造は第1 圖に見るよ5に, 概略の構造 は次の通りであります。

(a) チップスクリーンにて精選された木材チップは, ブロアによりサイロに送られテーブルフィーダー・バ ケットェレベーターを經てチップホッパーに入ります が，チップ內に混入している金屬片をマグネットセパ レーターにて除去します。次に木材チップは計量され た一定量の木材チップが低壓側ロータリーフィーダー に选り込まれます。スクリニーフィーダーにて藥液は スクリニーフィーダーのチップホッパーから適量を供 給しチップ瀻維組織內に藥液を浸透させます。

(b) 藥液を浸透された木材チップはスチーミグンベ ッセルにて低壓蒸氣で豫備蒸募されます。その低壓蒸

第 1 圖 日立造船型連續式七ミケミカルパルプ製造裝置構造圖

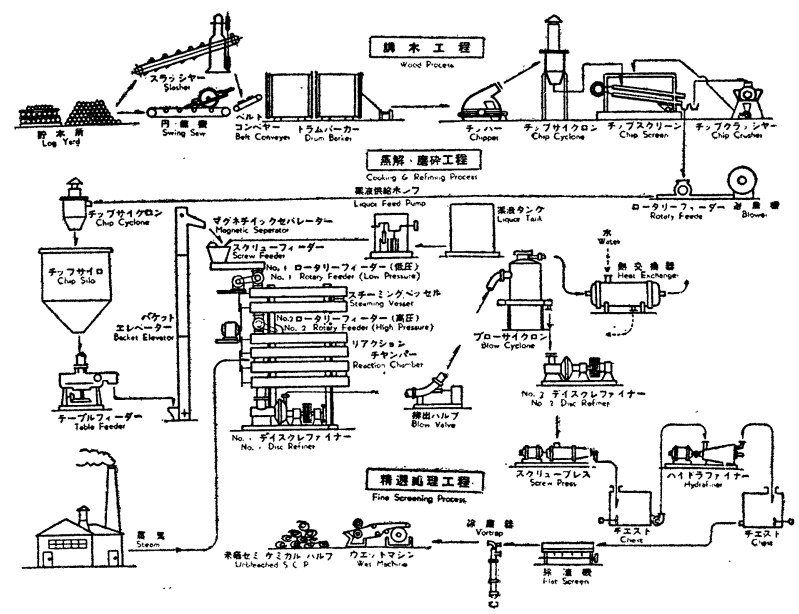




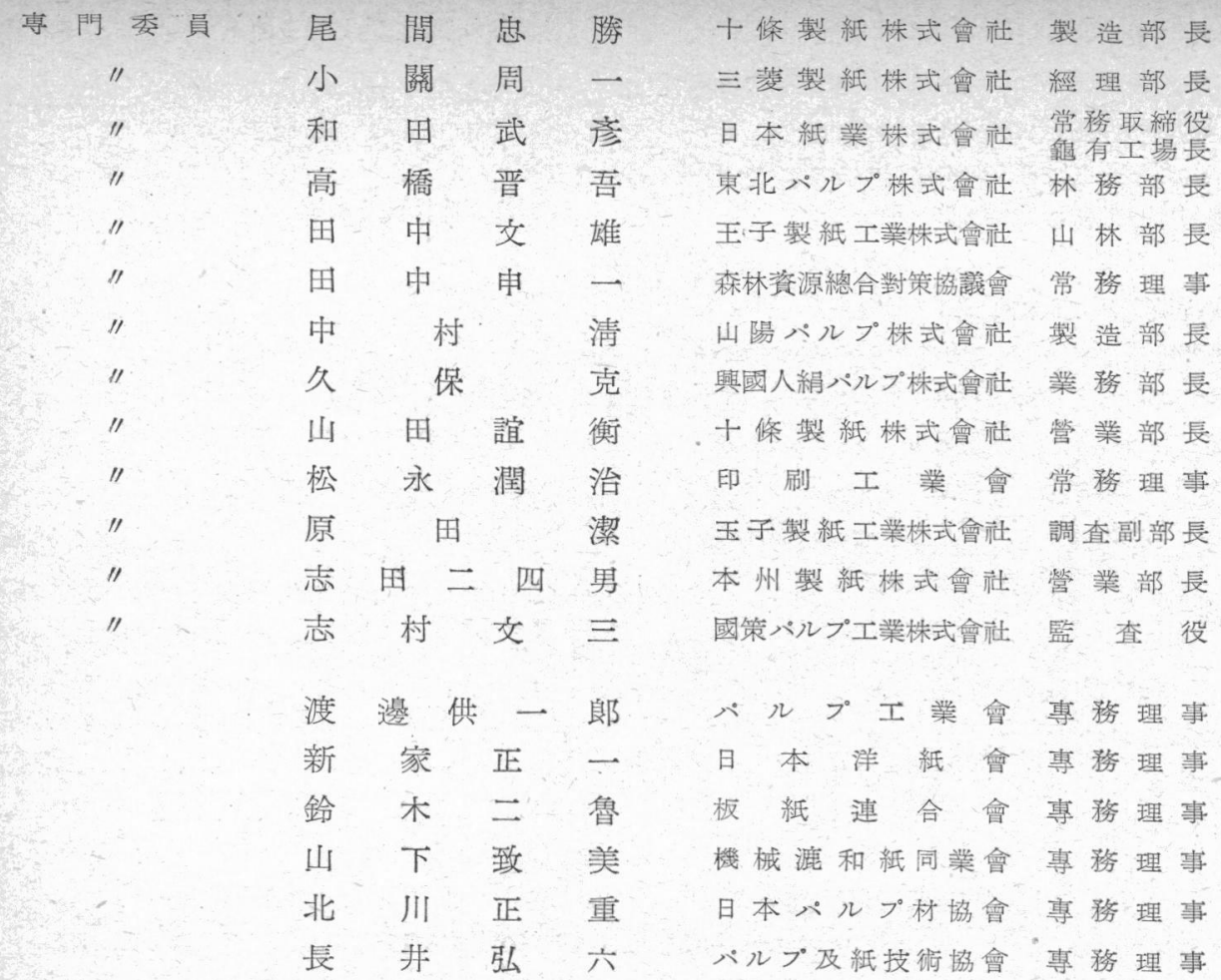

事務局

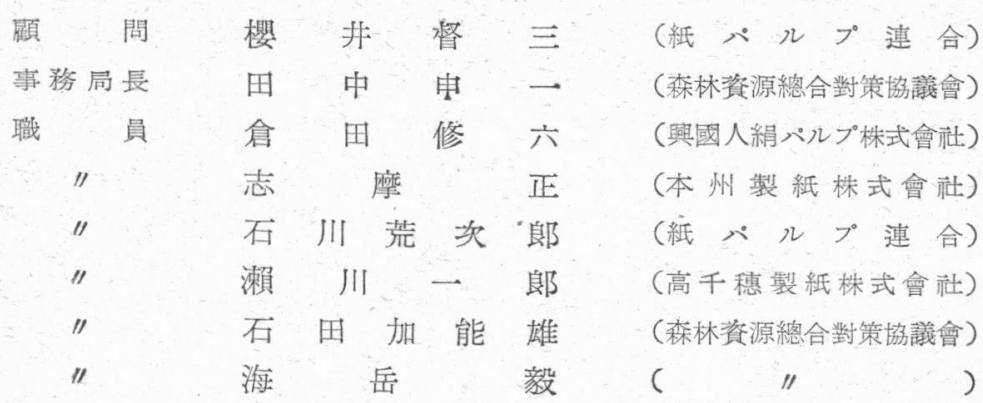

\section{第 8 回パルプ人繊技術研㶢會議事錄}

昭和27年11月27，28日

於 日本化學繊維協會大阪芳部

\section{第 1 日}

1.開會の爵

化繊側 大竹委員長

2. バルプ各社現況報告

3. 化纎各社現況報告

4.人瀻パルプ品質試驗成績及び使用賽績發表

5. パルプ手合せ分析試驗結果の檢討

第3 回分（興國人絹バルプ）

第4 回分 (山陽パルプ)

6. そ $\odot$ 他
7. 研究發表

1）高周波乾燥によるパルプ分析方法に就て

東北パルプ株式會㖣

2) レーヨンパルプの乾燥に就て

國策パルプ工業株式會社

3）レーヨンパルプの浮きに關する一考察

興國人絹パルプ株式會社

4）パルプ製品分析値の信賴度に就て

山陽バルプ株式會新

5) 人造繊維製造工程中の繊維素及びその誘導體 の微細棈造

倉敷レイシン株式會社 
6) パルプ中の灰分に就て

東洋レーヨン株式會社

7) パルプ中の灰分の組成分析結果に就て

東邦レーヨン株式會社

8）未溶解㽣維と濾過度の測定法

東洋紡績株式會社

9）樹脂抽出溶齊の檢討

10）溶缡別樹脂抽出結果の檢討

新光レイヨン株式會社

11）浮上り測定結果に就て

東邦レーヨン株式會社

12）パルプの浮上りに留する調査

倉敷レイヨン株式會社

8. 會 食

第 2 日

1. 米國 R.P. の技䘗的問題に就て

東北パルプ株式會社 山本純三郎氏

2.イタリヤの蔁パルプに就て

倉敷レイヨン株式會社 女成九十九氏

-3. 閉會の辭

バルプ側 井戸川委員長

以上

出席者 (略敬稱, 順序不同)

ペルプ側 (26名)

東北バルプ株式會社 井戶川春三, 長尾靜雄, 山本 純三郎, 米谷稳, 淺岡宏

日本パルプ工業怢式會哃 杉本一臣，土屋國夫，大 塚明, 山下光一, 新保禧三郎

北越製紙株式會社 高松孝一, 川村實作, 內山誠一 興國人絹パルプ株式會社 山田功, 田藤邦輔, 宮崎 武良, 三好康之

: 山陽パルプ株式會神: 中村清, 西澤篤志, 仙田雄藏 大久保正道, 光澤健治

:國策パルプ工業株式會社 汇口宏, 伊藤長, 太門徹 常盤康夫

能繊側 (39名)

帝國人造絹絲株式會社 中原久男

東洋レーヨン袾式會社三好重雄, 中島英彦, 吉田 瑞樹, 㲘谷繁藏

倉敷レイヨン株式會哐，友成九十九，吉本邦夫，藤 川正辰, 山川芳一, 松田俊男

東洋紡績株式會社 菊地義郎, 鹿江正男, 埴岡鶴市 旭化成工業株式會社 野間忠夫

日本レイヨン株式會社 舞田健三，竹原茂夫

新光レイヨン株式會社 北里又郎, 尾鷿壽郎, 久保 田政市，時友聰一

東邦レーヨン株式會社 大竹伊入, 澤登四朗, 营田茂 富士紡績怢式會社、阪本吉之助，中川正德

四東紡績株式會社 安田定雄, 前川實
大日本紡績株式會社 河野修次, 齊藤惠, 古田弘夫 興國人絹バルプ株工式會社 有澤幸夫，甲元康雄 鐘淵紡績株式會社 滕原耕司

大和紡績株式會社 中村義之, 村田政二

日本化學繊維協會 林英太郎, 荒井清, 重森晋策, 川名敏弘

$$
\text { 合 計 } 65 \text { 名比 }
$$

第 1 日

東邦レーヨン大竹氏司會のるとに 27 日午前 10 時より 議事に入る

\section{1. 開會の敆}

\section{化繊側 大竹委員長}

第 8 回バルプ人瀻研究會を開くに當り御多忙中にる 不拘遠路多數の御參會を得ました事に對し厚く御禮申 上げます。

本研究會も回を重㸚る每に充實しその業績には見る ベきものがあつたが更によく本會の發展且兩業界の進 展を期したいと存じます。

會議運營の方針は國產パルプ品質向上の爲の技術部 門に限定されたく思つて居ります。

佾本會で發表された data は內輪で運營願い度い事 を付け加え直ちに議事に入りたいと存じます。

挨撸後直ぐに議事比入る。

\section{2、パルプ各社現況報告}

國

策

老木が多い爲原木事情逼迫しレーンョパルプの生 產量增加は困難で专る12月の R.P. から高濃度晒, ドラムバーカーの整備, 定濃度チェストが完成した ので品質は向上し, 夏頃から水分斑は稍々少くなら た。

東 北 (秋田)

27 年 4 〜 10月。は品質向上に努力したが，未ナと滿 足點には達してない。 $\alpha$-cell 91\%以上，濶葉樹の樹 脂除去に成功し，10月は最高 0.19 , 最低 $0.15 \%$ でむ つた。蒸解自動調節機 1 基が出來濶葉樹蒸解に使用 している。12月には 2 基， 1 月には殘り 3 基も完成 の豫定である。

北越

全生產量の牛分がレーヨンパルプである。

設㣁は後處理設備を完成し明年は確實に期待に沿い 度い。

興一人

品質管理の糸底を期乙均一性のむるるのを目標と してるる。水分の閣題で迷惑をかけたが 1 年前から 原因を探究し改良した。 9 月以降は大分直つたと思 う。生產量は年間 40,000 噸殆どレーヨンパルプであ る。 1 部三菱製紙向バライタ用バルプである。

山陽

生產量は日產 160 噸であり，レーヨンパルプ以外 のもりは日坆 $30 \sim 40$ 噸である。設備は 6 月に高濃度 